\title{
DRY CONTINENT DREAMING: AUSTRALIAN VISIONS OF USING ANTARCTIC ICEBERGS FOR WATER SUPPLIES
}

\section{Abstract}

This article traces the little-studied development of Australian interest in iceberg utilisation from the 1960s to the early 1990s. Fostered by Cold War global anxieties about water availability, iceberg utilisation offered a means to overcome hydrological limits to growth. Drawing on Patrick McCray's characterisation of the 'visioneer', this article examines the arguments that Australian scientists raised in support of iceberg utilisation during the 1970s and 1980s. Focusing on Perth, Western Australia, as a prospective destination for harvested Antarctic icebergs, Australian visioneers appealed to settler narratives of heroic water engineering, and Antarctic exploration and exploitation. Although their scheme for iceberg utilisation was unrealised, its study reveals the particular circumstances that shaped the visioneers and their vision as well as the circumstances that hindered their achievement.

Keywords: iceberg utilisation, environmental history, Antarctica, limits to growth, Australia

\section{Dry continent dreaming}

On a wet Saturday morning in early 1978, Australians woke to the news that an iceberg was being towed into Sydney Harbour. Radio and television stations announced this incredible sight and broadcast its progress towards the Opera House as Sydneysiders flocked to witness the iceberg's arrival. For months, newspapers had reported that the iceberg cometh: Australian entrepreneur Dick Smith would captain the voyage and he promised to carve the iceberg into ice-cubes ('Dicksickles'), which he would sell for 10 cents each. Just the previous year, Smith, an accomplished aviator and businessman, had organised the first Australian sightseeing flights over 
Antarctica. ${ }^{1}$ As 'Dickenberg One' approached the harbour, however, the pouring rain revealed that the 'iceberg' was in fact a pile of firefighting foam and shaving cream: it was April Fool's Day and Smith had played a practical joke on the nation. ${ }^{2}$

Smith's prank paled in comparison to a stunt that had unfolded just six months earlier. In October 1977, scientists had met at Iowa State University to discuss the latest findings in the emerging field of 'iceberg utilisation'. ${ }^{3}$ Eager to promote the cause was conference co-sponsor Prince Mohammed al-Faisal of Saudi Arabia, who flew an iceberg weighing more than two tonnes from the Portage Glacier field near Anchorage, Alaska, to Ames, Iowa, for the occasion-a distance of nearly $6,000 \mathrm{~km}$. One local couple, who brought with them plastic bags, a bucket and an ice pick to the iceberg's unveiling, told the New York Times that they 'don't know what we'll do with it—serve it in drinks, I guess. We'll have a cocktail party'. ${ }^{4}$

While these stunts occupied the headlines, behind the scenes were researchers studying the possibility of using Antarctic icebergs to supply water to cities in arid and semi-arid climes. Even Smith himself had considered towing an iceberg to Australia for such purposes, before pulling his prank instead. ' 'Iceberg utilisation' was a tantalising prospect for solving one of the world's pressing problems: global water shortages. The Club of Rome had earlier warned that the availability of fresh water was a limit to growth that 'will be reached long before the land limit becomes apparent' ${ }^{6}$ Bolstering this neo-Malthusian prediction were the widely reported droughts in the Sahel and the Ukraine, and the failure of the Indian monsoon during the early 1970s.

1 The author is grateful for the assistance of archivists at the Fenner Archives, Australian Academy of Science (AAS); Iowa State University Special Collections and University Archives (ISU); National Archives of Australia (NAA Adelaide, Canberra, Melbourne and Perth); State Records Office of Western Australia; and the Water Corporation of Western Australia (WCWA). This article has benefited enormously from the generous participant feedback at the conferences 'Global Deserts: Environmental History in the Arid Lands', University of Arizona, Tucson, 14-15 September 2015 (especially Gary Reger for his insightful commentary), and 'Foreign Bodies, Intimate Ecologies: Transformations in Environmental History’, Macquarie University, Sydney (especially Ian Tyrrell and Tom Griffiths). Thanks also to Alessandro Antonello, Mark Carey, Dagomar Degroot, Andrea Gaynor, Michael Christopher Low, Rafico Ruiz, history colleagues at Monash University, and the anonymous reviewers for their advice and support. This research was funded by the Australian Research Council (DE160101125); the Alexander von Humboldt Foundation; and the Rachel Carson Center for Environment and Society, Ludwig-Maximilian University, Munich. Thomas Bauer, 'Antarctic Scenic Overflights', in Prospects for Polar Tourism, ed. John Snyder and Bernard Stonehouse (Wallingford, Oxon.: CAB International, 2007), 190.

2 'Fake Iceberg Towed into Sydney as Prank', New York Times, 2 April 1978, 4; Richard Fidler, 'Dick Smith reveals how he became a successful businessman', Conversations with Richard Fidler (Australian Broadcasting Corporation, 12 April 2006), www.abc.net.au/local/stories/2006/04/12/1614826.htm, accessed 5 May 2017.

3 A. A. Husseiny, ed., Iceberg Utilization: Proceedings of the First International Conference and Workshops on Iceberg Utilization for Fresh Water Production, Weather Modification and Other Applications, Held at Iowa State University, Ames, Iowa, USA, October 2-61977 (New York: Pergamon, 1978).

4 Douglas E. Kneeland, 'An Alaskan Iceberg Upstages a Saudi Prince at Conference in Iowa', New York Times, 7 October 1977, 23.

5 A. E. Humphreys, Enquiries from the Press, 23 February 1977, 58. Antarctic Program Administration, Advice, Economic Resources, Krill and Iceberg Utilisation for Fresh Water, 1976-1982. B1387, 81/70, NAA.

6 Donella H. Meadows, Dennis L. Meadows, Jørgen Randers and William W. Behrens III, The Limits to Growth: A Report for the Club of Rome's Project on the Predicament of Mankind (New York: Universe Books, 1972), 53. 
These anxieties were the focus of the 1977 United Nations Conference on Water in Mar del Plata, Argentina, where fresh water was declared a 'scarce asset' that demanded coordinated resource development and management. ${ }^{7}$ Among the options discussed to increase water supplies were so-called 'complex technologies' and 'non-conventional methods', such as seawater desalination. ${ }^{8}$ By the late 1970 s, desalination was already well established in Kuwait, and Saudi Arabia was eager to replicate its neighbour's success. ${ }^{9}$ Leading this mission was the head of the Saudi Saline Water Conversion Corporation, Prince Mohamed al-Faisal-that is, at least until Antarctic icebergs beckoned.

The prospect of using icebergs to provide endless water supplies for the world's thirstiest regions had emerged in the decade after the Second World War. In a 1949 class at the Scripps Institution of Oceanography in California, the oceanographer John Isaacs had speculated on the subject, and later expanded on his thinking in the February 1956 issue of Science Digest. ${ }^{10}$ He suggested floating an Antarctic iceberg along the Humboldt Current along the western coast of South America to the coast of southern California, from where it could supply water to Los Angeles. ${ }^{11}$ The feasibility of such a scheme was confirmed in 1969, when two American scientists, the glaciologist Willy Weeks and the geophysicist Bill Campbell, surprised even themselves when they concluded that towing icebergs to arid lands was 'within the reach of existing technology'. ${ }^{12}$ They based their calculations on a large tabular iceberg twice the size of the Great Pyramid of Giza, which was less likely to roll in transit and more likely to be found near the Antarctic than the Arctic. ${ }^{13}$

7 United Nations, Report of the United Nations Conference, Mar del Plata, 14-25 March 1977 (New York: United Nations, 1977), 95, 97. See Jeremy J. Schmidt, Water: Abundance, Scarcity, and Security in the Age of Humanity (New York: NYU Press, 2017), 115-40.

8 United Nations, Report of the United Nations Conference, 36.

9 Farah Al-Nakib, Kuwait Transformed: A History of Oil and Urban Life (Palo Alto, CA: Stanford University Press, 2016); Toby Craig Jones, Desert Kingdom: How Oil and Water Forged Modern Saudi Arabia (Cambridge, MA: Harvard University Press, 2010); Masahiro Murakami, Managing Water for Peace in the Middle East: Alternative Strategies (Tokyo: United Nations University Press, 1995), 115-20. Michael Low shows that the Saudi entanglement of potable water supplies and oil reserves had its roots in the long nineteenth century, see Michael Christopher Low, 'Ottoman Infrastructure of the Saudi Hydro-State: The Technopolitics of Pilgrimage and Potable Water in the Hijaz', Comparative Studies in Society and History 57, no. 4 (2015), doi.org/10.1017/S0010417515000407.

10 Daniel Behrman with John D. Isaacs, John Isaacs and His Oceans (Washington, DC: ICSU Press, 1992), 49; Leonard Engel and the Editors of Time-Life Books, The Sea (New York: Time, 1961).

11 Jesse C. Burt, 'Iceberg Water for California?', Science Digest 39, no. 2 (1956): 1-4. See also Jesse C. Burt, 'The Battle for the Bergs', Natural History 65, no. 4 (1956): 186-91; Daniel Behrman and John D. Isaacs, John Isaacs and His Oceans (Washington, DC: American Geophysical Union, 1992), 50-2.

12 Wilford J. Weeks and William J. Campbell, 'Icebergs as a Freshwater Source: An Appraisal', Journal of Glaciology 12, no. 65 (1973): 207-33. For Weeks' reflections on this research, see Wilford J. Weeks, interview by Brian Shoemaker (17 April 2000), Byrd Polar Research Center Archival Program, Ohio State University, kb.osu. edu/dspace/handle/1811/32165.

13 Weeks and Campbell, 'Icebergs as a Freshwater Source', 215. The dimensions of the hypothetical iceberg were $920 \mathrm{~m}$ (length) x $230 \mathrm{~m}$ (width) x $250 \mathrm{~m}$ (thickness). 
One of the two prospective ports on which Weeks and Campbell had based their calculations was on the south-west coast of Australia. According to their research, icebergs could be towed there from the Amery Ice Shelf with the assistance of 'very favourable' winds and currents, a distance of nearly 7,000 km across the Southern Ocean. ${ }^{14}$ Following a report on southern California's feasibility as a destination, which had been sponsored by the National Science Foundation and the Rand Corporation, researchers associated with the Australian Academy of Science completed their own inquiry in $1976 .{ }^{15}$ Chaired by the South Australian meteorologist Peter Schwerdtfeger, this investigation concurred with the earlier findings and added the coast of South Australia as another ideal destination for icebergs. ${ }^{16}$ Participants in this investigation, including Schwerdtfeger, were among a small contingent of Australian scientists who attended al-Faisal's Iowa conference the following year. Schwerdtfeger would continue to espouse iceberg utilisation for Australian cities over the subsequent two decades, undeterred by the relatively subdued interest of Australian water managers.

This article traces the little-studied development of Australian interest in iceberg utilisation from the 1960s to the early 1990s. In addition to the geopolitics and natural resource anxieties of the Cold War era, the advocacy of iceberg harvesting in Australia was informed and sustained by two national legends-one of heroic water engineering schemes, and the other of Antarctic exploration and exploitation. The first envisioned the application of science and technology to overcome the limits that scarce water supplies posed to the nation's economic development, while the latter conjured feats of heroic endurance in hostile climes. Both legends valorised grand schemes of human ingenuity that would dominate a wilful nature to sustain the settler colonial project. ${ }^{17}$ Just as rivers might be turned inland and the deserts made to bloom, so too might Antarctic icebergs be hauled north to water the capitals of the driest states on the driest inhabited continent on earth. This settler water dreaming was no match, however, for the dry reality of Australian water resource management in an era of rising energy costs.

14 Weeks and Campbell, 'Icebergs as a Freshwater Source'.

15 J. L. Hult and N. C. Ostrander, Antarctic Icebergs as a Global Fresh Water Resource (Santa Monica, CA: Rand, 1973).

16 Peter Schwerdtfeger, 'Report of the Committee Investigating the Use of Icebergs as a Potential Source of Fresh Water', 18 May 1976. Possible Use of Antarctic Icebergs for Supply of Water. B1387, 91/478, NAA.

17 Mark Carey, M. Jackson, Alessandro Antonello and Jaclyn Rushing, 'Glaciers, Gender, and Science: A Feminist Glaciology Framework for Global Environmental Change Research’, Progress in Human Geography 40, no. 6 (2016), doi.org/10.1177/0309132515623368. 


\section{Cold War water dreaming}

The possibility of iceberg utilisation was one of many post-war technological imaginaries. The futurism and science fiction of the atomic age urged the exploration and exploitation of new planetary frontiers such as the deep ocean and outer space. ${ }^{18}$ In the Cold War context, measuring, monitoring and manipulating the physical environment at a global scale had the potential to fulfil both military and peaceful ambitions. ${ }^{19}$ It was the latter to which men like al-Faisal, Smith and Schwerdtfeger aspired - to enhance the availability of fresh water. ${ }^{20}$ For al-Faisal at least, iceberg technology represented a means to achieve accelerated economic development for his country, 'to be equal with the rest of the world'. ${ }^{21}$ The Australian proponents implicitly shared this Saudi sociotechnical imaginary: abundant water supplies would facilitate the nation's ongoing economic and population growth, and ensure political and social stability in the wake of the turbulent $1970 \mathrm{~s}^{22}$

Vast water engineering schemes have long dominated sociotechnical imaginaries, promising to unlock the potential of thirsty lands and peoples. In the first half of the twentieth century, utopian engineers sought to redeem the seemingly deficient colonial environments of southern and northern Africa. ${ }^{23}$ In the meantime, hydroelectricity fuelled the superpower rivalry between the United States and the Soviet Union, while dams would famously be the 'temples of modernity' in Jawaharlal Nehru's newly independent India. ${ }^{24}$ Australians too shared this appetite for advancement by hydrological means, producing a pantheon of what the historian Michael Cathcart describes as the 'water dreamers'. ${ }^{25}$ Since the nineteenth century,

18 For an example of the influence of science fiction on scientific research, see Helen M. Rozwadowski, 'Arthur C. Clarke and the Limitations of the Ocean as a Frontier', Environmental History 17, no. 3 (2012), doi.org/10.1093/ envhis/ems046.

19 Jacob Hamblin, Arming Mother Nature: The Birth of Catastrophic Environmentalism (New York: Oxford University Press, 2013).

20 See Peter Schwerdtfeger, 'On Icebergs and their Uses: A Report to the Australian Academy of Science', Cold Regions Science and Technology 1 (1979): 59-79.

21 Cited in Dana Adams Schmidt, 'Can you lead an iceberg to the desert?', Christian Science Monitor, 21 November $1975,1,11$.

22 Sheila Jasanoff and Sang-Hyun Kim, 'Containing the Atom: Sociotechnical Imaginaries and Nuclear Power in the United States and South Korea', Minerva 47, no. 2 (2009): 119-46; Sheila Jasanoff and Sang-Hyun Kim, eds, Dreamscapes of Modernity: Sociotechnical Imaginaries and the Fabrication of Power (Chicago: University of Chicago Press, 2015).

23 Meredith McKittrick, 'An Empire of Rivers: The Scheme to Flood the Kalahari, 1919-1945', Journal of Southern African Studies 41, no. 3 (2015), doi.org/10.1080/03057070.2015.1025339; Philipp N. Lehmann, 'Infinite Power to Change the World: Hydroelectricity and Engineered Climate Change in the Atlantropa Project', American Historical Review 121, no. 1 (2016), doi.org/10.1093/ahr/121.1.70.

24 See, for example, Paul Josephson, 'War on Nature as Part of the Cold War: The Strategic and Ideological Roots of Environmental Degradation in the Soviet Union', and Richard Tucker, 'Containing Communism by Impounding Rivers: American Strategic Interests and the Global Spread of High Dams in the Early Cold War', in Environmental Histories of the Cold War, ed. J. R. McNeill and Corinna R. Unger (New York: Cambridge University Press, 2010), 21-50 and 139-66.

25 Michael Cathcart, The Water Dreamers: The Remarkable History of Our Dry Continent (Melbourne: Text Publishing, 2010). 
settler Australians have imagined ways to overcome the continent's aridity, refusing to yield their ambitions to its hydrological limits. Even hydro-imaginaries that have not come to pass lurk in the national consciousness, waiting to bubble to the surface when the next water crisis is declared. ${ }^{26}$

Although the ghosts of the water dreamers loomed large over the Australian iceberg advocates, their focus on the urbanised south of the continent distinguished their plan from most earlier and contemporary hydro-imaginaries. Here, water was not intended to initiate development, as it was hoped in the tropical north or the arid inland, but, instead, to sustain it. ${ }^{27}$ What also set them apart was the constellation of Cold War concerns in which their ambitions were situated: where science and technology were fused with business and politics to shape their projections of a limitless future. Theirs was a venture that 'require[d] risk-taking, not only from the science and technology standpoint, but also as an entrepreneurial venture', as Guyford Stever, a former science advisor to presidents Richard Nixon and Gerald Ford, and director of the US National Science Foundation, declared to the attendees at Iowa State University. ${ }^{28}$ Such circumstances, the historian W. Patrick McCray suggests, produced the 'visioneer', a hybrid character of 'futurist, researcher, and promoter', whose ideas 'may have seemed fantastical, [but] were not impossible'. Importantly, visioneers were not recklessly speculative-they sought to realise their visions within their own lifetimes. They would inhabit their imagined future. ${ }^{29}$

The Australian proponents of iceberg utilisation embodied these characteristics of McCray's 'visioneers'. As a consequence of their seemingly far-fetched scheme, they struggled to reconcile their desire for publicity and commercialisation with the need to uphold the scientific credibility of the project for state and peer support. Although these tensions, combined with economic and environmental forces, conspired to thwart their scheme to ensure limitless water supplies for southern Australia, such unrealised visions or 'failed projects' warrant closer historical inspection. Their study can reveal the particular circumstances that shaped the visioneers and their vision, as well as the circumstances that hindered their achievement. ${ }^{30}$ The 'visioneers' of iceberg utilisation were a product of local and global anxieties about the availability of freshwater supplies that forecast a grim future of scarcity—a future they believed could be avoided.

26 Tim Sherratt and Tom Griffiths, 'What if the Northern Rivers had been Turned Inland?', in What If? Australian History as it Might Have Been, ed. Stuart Macintyre and Sean Scalmer (Carlton, Vic.: Melbourne University Press, 2006), 234-54.

27 See Libby Robin, How a Continent Created a Nation (Sydney: UNSW Press, 2007), 123-51.

28 H. Guyford Stever, 'New Patterns of Cooperation in International Science and Technology', in Iceberg Utilization, ed. Hussieny, 2.

29 W. Patrick McCray, The Visioneers: How a Group of Elite Scientists Pursued Space Colonies (Princeton, NJ: Princeton University Press, 2013), 14, 17.

30 Manu Goswami, 'Imaginary Futures and Colonial Internationalisms', American Historical Review 115, no. 5 (2012), doi.org/10.1093/ahr/117.5.1461; McCray, The Visioneers, 18. 


\section{lceberg imperialism}

South-western Australia had already been flagged as a location that could benefit from iceberg utilisation several years before the feasibility study by Weeks and Campbell. In 1965, the private Western Australian Corporation had approached the Australian Antarctic Division regarding the possibility of hauling an iceberg to the west of the Great Australian Bight. ${ }^{31}$ An iceberg could provide water supplies for a stretch of land that the New York-based syndicate sought to develop-nearly 2 million hectares of semi-arid sandplain stretching along the south coast from Norseman to within $80 \mathrm{~km}$ of the South Australian border. ${ }^{32}$ Although the syndicate's vision did not eventuate, its ambitions appealed to a conservative government that promoted rapid agricultural development through the clearing of 'a million acres a year' in the state's wheatbelt. ${ }^{33} \mathrm{~A}$ decade later and further north, a spell of dry years was taking its toll on the suburbs of Perth, which had undergone rapid growth since the mid-1960s. The city's rising population prompted the Western Australian state government to consider how it would ensure sufficient water supplies to sustain the mining boom. Projections produced in 1973 of the region's water demand in the early twenty-first century alarmed the Metropolitan Water Board and the Public Works Department, as figures suggested demand would exceed available supplies by the mid-1980s. The danger of demand soon exceeding supplies drove many of the investigations into alternative water sources for the city during the mid-1970s, such as exploiting groundwater reserves and piping water from the north-west of the state. ${ }^{34}$

31 T. F. C. Lawrence to H. C. Webster, 'Icebergs as a Source of Fresh Water', 6 July 1971. Possible Use of Antarctic Icebergs for Supply of Water. B1387, 91/478, NAA.

32 Athol Thomas, 'The Cabinet Flies to Wombat Land', Canberra Times, 20 March 1967, 2. The Western Australian Corporation was registered in New York in February 1965, and added 'Development' to its title later that year.

33 In addition to its plans for the south coast of Western Australia, the syndicate proposed developing commercial buildings and railways in the state's capital, Perth. The corporation folded in 1982, by which time it was registered as the Technical Projects Corporation. See New York State Department of State, Division of Corporations Entity information (8 February 2017), appext20.dos.ny.gov/corp_public/corpsearch.entity_search_entry; T. F. C. Lawrence to H. C. Webster, 'Icebergs as a Source of Fresh Water', 6 July 1971. Possible Use of Antarctic Icebergs for Supply of Water. B1387, 91/478, NAA; Western Australian Development Corporation, Skidmore, Owings \& Merrill, and Peet \& Co., Perth World Trade Centre (Perth: Western Australian Development Corporation, 1967); and Western Australian Development Corporation and J. O. Clough \& Son, Final Proposal for Perth Railway Development Project (Perth: Western Australian Development Corporation, 1968). For an insight into the ecological and social impacts of the state government's agricultural development policies, see Quentin Beresford, Hugo Bekle, Harry Phillips and Jane Mulcock, The Salinity Crisis: Landscapes, Communities and Politics (Crawley: UWA Publishing, 2001); Andrea Gaynor, 'Looking Forward, Looking Back: Towards an Environmental History of Salinity and Erosion in the Eastern Wheatbelt of Western Australia', in Country: Visions of Land and People in Western Australia, ed. Andrea Gaynor, Anna Haebich and Mathew Trinca (Perth: WA Museum, 2002), 105-24; Ruth A. Morgan, Running Out? Water in Western Australia (Crawley: UWA Publishing, 2015), 71-96.

34 Morgan, Running Out?, 106-8. 
Similar problems were forecast to affect the South Australian capital, Adelaide. In 1972 the state government's Committee on the Environment warned that growing demand for water would exhaust available supplies by the end of the century. This prediction encouraged Schwerdtfeger, newly appointed Foundation Professor of Meteorology at the state's Flinders University, to form a committee to undertake an Australian inquiry into iceberg utilisation under the auspices of the Australian Academy of Science. ${ }^{35}$ Schwerdtfeger, who had undertaken his doctoral research on sea ice physics in Canada, assembled a team of local experts to work on the problem. From the outset, the project raised eyebrows within the Academy; its Secretary (Physical Sciences) defended the committee in a letter to a colleague: 'The Academy Council has been assured that the project is scientifically respectable' ${ }^{36}$ The Adelaide zoologist W. P. 'Buddy' Rogers, who was described as having 'fathered the project', downplayed his colleagues' incredulity in a letter to a federal parliamentarian: 'imaginative schemes of this sort always stimulate the most conservative opposition'. ${ }^{37}$

In addition to the matter of scientific credibility, Schwerdtfeger's committee faced the issue of attracting the interest of the federal government. Even before his committee had formed, the Australian Water Resources Council had declined to contribute to the Rand Corporation's research because it deemed their proposal was unlikely 'to produce a viable scheme'. ${ }^{38}$ The Federal Department of Science also expressed its misgivings after local reports of the Weeks and Campbell study had prompted inquiries from the public about iceberg utilisation in the Northern Territory. ${ }^{39}$ One public servant dismissed the prospect as a 'pet theory' of Weeks, who was apparently 'up to his old tricks again'. ${ }^{40}$ Not surprisingly, Rogers' entreaty to his federal representative for Commonwealth support was rejected on the grounds that a 'real demand for additional water should be demonstrated by the authorities concerned before any major effort is put into detailed feasibility studies'. ${ }^{41}$

35 Peter Schwerdtfeger, Southern Ocean Studies Relating to Icebergs (Adelaide: Flinders Institute for Atmospheric and Marine Sciences, 1981), 1. The committee members were Schwerdtfeger (chair), W. F. 'Bill' Budd, T. Chapman, J. Job, A. McEwan, T. K. Spillane and E. Tuck. See Peter Schwerdtfeger, 'Report of the Committee Investigating the Use of Icebergs as a Potential Source of Fresh Water', 18 May 1976. Possible Use of Antarctic Icebergs for Supply of Water B1387, 91/478, NAA.

36 E. S. Barnes to K. L. Sutherland, 25 July 1974. Iceberg Project, Nov. 1973-Nov. 1977. John Robert Philip Collection, AAS.

37 W. Rogers to R. Jacobi, 30 July 1974. Possible Use of Antarctic Icebergs for Supply of Water B1387, 91/478, NAA; O. Frankel to A. F. McIntyre, 17 January 1974. Iceberg Project, Nov. 1973-Nov. 1977. John Robert Philip Collection, AAS.

38 R. J. Richards to N. C. Ostrander, 3 December 1971. Possible Use of Antarctic Icebergs for Supply of Water. B1387, 91/478, NAA.

39 B. Wright to W. Morrison, 5 November 1973 and 16 October 1974. Possible Use of Antarctic Icebergs for Supply of Water. B1387, 91/478, NAA.

40 Memorandum, 6 June 1973. Possible Use of Antarctic Icebergs for Supply of Water. B1387, 91/478, NAA.

41 A. F. Rainbird to W. Morrison, 7 August 1974. Possible Use of Antarctic Icebergs for Supply of Water. B1387, $91 / 478$, NAA. 
The Academy's committee persevered regardless. ${ }^{42}$ In his final report on the investigation, Schwerdtfeger explained the nature of iceberg dynamics, and recommended that further research should advance beyond theoretical work to 'laboratory and field experimental studies, the latter involving actual icebergs'. ${ }^{43}$ Despite Schwerdtfeger's confidence that an 'Iceberg Instrumentation Program' could proceed with the assistance of the Australian Antarctic Division, the Commonwealth Scientific and Industrial Research Organisation (CSIRO) Division of Fisheries and Oceanography and the CSIRO Division of Atmospheric Physics, the Academy was reluctant to support the project further. ${ }^{44}$

Six months after Schwerdtfeger recommended the disbanding of the committee in early 1977, he led a small group of Australian scientists to Iowa at the invitation and expense of the conference organisers. Among them were the glaciologist Bill Budd and the chemical engineering student Jonathan Job, who had both served on Schwerdtfeger's committee, as well as the physicist Vin Morgan, Budd's colleague in the Australian Antarctic Division, and Don Miles of Western Australia, a self-described 'generalist'. They joined a group of more than 100 attendees, many of whom were associated with the US military-industrial-academic complex, including researchers from the Jet Propulsion Laboratory, Tetra Tech International, the Lawrence Berkeley Laboratory, the US Army Cold Regions Research and Engineering Laboratory, and the Naval Weapon Centre. ${ }^{45}$ After all, iceberg utilisation was not only a possible means to supplement water supplies, it might also facilitate weather and climate control for civil and martial purposes. ${ }^{46}$

On his return to Australia, Morgan reported to his superiors in the Antarctic Division. He wrote: 'The final feeling seemed to be that iceberg transporting was worthwhile pursuing but that there was a lot of work to be done before any ice would be delivered'. ${ }^{47}$ In addition, he assured his supervisors that iceberg utilisation would not contravene the terms of the Antarctic Treaty, which he noted, 'specifically excludes the high seas from its provisions and ... makes no mention of resource exploitation'. ${ }^{48}$ Contemporary legal scholarship was more cautious than Morgan's

\footnotetext{
42 P. Schwerdtfeger, 18 May 1976. 'Possible Use of Antarctic Icebergs for Supply of Water'. B1387, 91/478, NAA.

43 Schwerdtfeger, 'Possible Use of Antarctic Icebergs for Supply of Water'.

44 CSIRO is the Commonwealth Scientific and Industrial Research Organisation. It was formed in 1949.

45 'List of Participants', in Iceberg Utilization, ed. Husseiny, 74-5; Stuart W. Leslie, The Cold War and American Science: The Military-Industrial-Academic Complex at MIT and Stanford (New York: Columbia University Press, 1993).

46 See R. W. Home, 'Rainmaking in CSIRO: The Science and Politics of Climate Modification', in A Change in the Weather: Climate and Culture in Australia, ed. Tim Sherratt, Tom Griffiths and Libby Robin (Canberra: National Museum of Australia Press, 2005), 66-79; James R. Fleming, Fixing the Sky: The Checkered History of Weather and Climate Control (New York: Columbia University Press, 2010); Hamblin, Arming Mother Nature; Kristine C. Harper, Make it Rain: State Control of the Atmosphere in Twentieth-Century America (Chicago: University of Chicago Press, 2017).

47 V. Morgan, 'Attachment A, "First International Conference on Iceberg Utilization for Freshwater Production, Weather Modification, and Other Applications, Ames, Iowa, 2-6 October, 1977”', April 1978. B1387, 81/70, NAA. 48 Morgan, 'Attachment A'.
} 
assessment, whereby the property rights pertaining to icebergs were largely uncertain under the Antarctic Treaty as well as the 1958 Convention on the High Seas and the 1958 Territorial Sea Convention. ${ }^{49}$ To his note on the legality of iceberg utilisation, Morgan added: 'The general thought was that there are plenty of icebergs freely floating off the coast of Antarctica and that these would be available as are fish in the sea to anyone wanting to collect some'..$^{50}$ Although Morgan conceded that this perception was simplistic, his report suggests that the vision for iceberg utilisation had reconfigured its subject from a dangerous hindrance to a natural resource that would otherwise be wasted.

The 'freely floating' icebergs to which Morgan referred were more problematic than his report suggested. For the North Atlantic in particular, icebergs were a terrifying reality of the high seas, even in the late 1950s, as the demise of the 2,875-ton Danish passenger-freighter Hans Hedtoft attested. ${ }^{51}$ In the Southern Ocean, meanwhile, Australia's polar vessels (the Thala Dan and Nella Dan) were regularly trapped in the belt of pack ice that surrounds the Antarctic. Harnessing icebergs, however, could turn the tables on this maritime foe. In the context of neo-Malthusian predictions of resource scarcity, it would be entirely logical to do so. Reflecting on this period in the 1980s, Stephen J. Pyne observed: 'What seemed technologically remote now seems plausible, and what appeared to be hopelessly expensive and unnecessary now appears potentially valuable and perhaps essential to national interests'. ${ }^{52}$ In the case of water shortages, Rand researchers John Hult and Neill Ostrander estimated in 1973 that more than a trillion cubic metres of Antarctic icebergs - a volume that is 2,000 times the size of Sydney Harbour-could be harvested annually without 'depletion or environmental damage'. This amount, they suggested, would 'satisfy the needs of an urban population of 4 to 6 billion people at 200 to $300 \mathrm{~m}^{3}$ of water per capita per year. This the current standard rate of consumption in the urban areas of the US Pacific Southwest'. ${ }^{53}$ Moreover, as Weeks and Campbell had earlier noted, the 'best aspect of the [iceberg towing] scheme is that its principal resource, the icebergs, are currently being completely wasted as regards man's needs'. ${ }^{54}$

49 See, for example, Thomas R. Lundquist, 'The Iceberg Cometh: International Law Relating to Antarctic Iceberg Exploitation', Natural Resources Journal 17 (1977): 1-41; Curt Epperson, 'International Legal Issues Regarding Towing of Icebergs and Environmental Effects of Iceberg Exploitation', in Law of the Sea: Neglected Issues, ed. John King Gamble (Manoa: Law of the Sea Institute, University of Hawai i, 1979), 209-39; Donald Rothwell, The Polar Regions and the Development of International Law (Melbourne: Cambridge University Press, 1996).

50 Morgan, 'Attachment A'.

51 Simon Haykin, Edward O. Lewis, R. Keith Raney and James R. Rossiter, Remote Sensing of Sea Ice and Icebergs (New York: John Wiley \& Sons, 1994), 43.

52 Stephen J. Pyne, The Ice (London: Weidenfeld \& Nicolson, 1986), 353.

53 Hult and Ostrander, 8-9. More recent estimates suggest that Antarctic glaciers shed more than 2.6 billion $\mathrm{m}^{3}$ of ice into the ocean each year, which is equivalent to about two-thirds of the world's annual freshwater consumption. See Mariana Gosnell, Ice: The Nature, the History, and the Uses of this Astonishing Substance (New York: Alfred A. Knopf, 2005), 168.

54 Weeks and Campbell, 231. 
The potential failure to take advantage of icebergs resonated with a settler Australian antipathy toward nature's 'waste' of water. ${ }^{55}$ Since the foundation of New South Wales in 1788 , the boom and bust of the continent's rainfall had proven a significant barrier to the development of colonial agriculture. ${ }^{56}$ To insure against lean years, a shared vision among the water dreamers emerged, a vision of water conservation. On the eve of Federation in 1901, for instance, poets and artists imagined the damming of floodwaters so that irrigated pastures could withstand drought's inevitable return. ${ }^{57}$ Others saw enormous potential in the continent's tropical rivers to water the arid inland-lest their waters flow, wasted, into the sea. ${ }^{58}$ Irrigated agriculture was also at the heart of Weeks and Campbell's vision: 'there, the water after being utilised for irrigation, eventually returns to the sea. The end result is the same, only the path is different'. ${ }^{59}$ Moreover, a single iceberg could irrigate 'roughly four times the amount [of land] provided by the Snowy Mountains Project', the beacon of Australia's postwar reconstruction effort. ${ }^{60}$

The concerns of water dreamers and iceberg visioneers about nature's 'waste' perpetuated a longer imperial concern with the 'improvement' of colonial environments. Only imperial rule would ensure that a territory's resources were not 'squandered' by either under-exploitation or over-exploitation. ${ }^{61}$ Such logic prevailed under the Antarctic Treaty System. The Antarctic Treaty, which Australia had ratified as one of the original 12 signatories in 1959, had enshrined a system that preserved what the historian Adrian Howkins describes as the 'frozen relics of Antarctic imperialism'. These relics - the sovereignty claims of the first half of the twentieth century_could be thawed should 'economically exploitable minerals' be

55 Heather Goodall, “"The River Runs Backward”, in Words for Country: Landscape and Language in Australia, ed. Tim Bonyhady and Tom Griffiths (Sydney: UNSW Press, 2002), 30-51. Similar arguments for development and extraction have appeared in other contexts. For example, the Soviet Union argued in the 1970s that the harvesting of krill in the Southern Ocean would avoid wasting this marine resource. See Alessandro Antonello, 'Protecting the Southern Ocean Ecosystem: The Environmental Protection Agenda of Antarctic Diplomacy and Science', in International Organizations and Environmental Protection: Conservation and Globalization in the Twentieth Century, ed. Wolfram Kaiser and Jan-Henrik Meyer (New York and Oxford: Berghahn, 2016), 283.

56 Don Garden, Droughts, Floods and Cyclones: El Niños that Shaped our Colonial Past (Melbourne: Australian Scholarly Publishing, 2009); Libby Robin, Robert Heinsohn and Leo Joseph, eds, Boom and Bust: Bird Stories for a Dry Country (Collingwood, Vic.: CSIRO Publishing, 2009).

57 Tim Bonyhady, The Colonial Earth (Carlton, Vic.: Miegunyah Press, 2000), 282-3; Tom Griffiths, 'The Outside Country', in Words for Country: Landscape and Language in Australia, ed. Tim Bonyhady and Tom Griffiths (Sydney: UNSW Press, 2002), 225; Emily O'Gorman, Flood Country: An Environmental History of the MurrayDarling Basin (Collingwood, Vic.: CSIRO Publishing, 2012), 6.

58 Sherratt and Griffiths, 238; Cathcart, The Water Dreamers, 233.

59 Weeks and Campbell, 231.

60 Weeks and Campbell, 231; Cathcart, The Water Dreamers, 238-41. See also Stuart Macintyre, Australia's Boldest Experiment: War and Reconstruction in the 1940s (Sydney: NewSouth, 2015).

61 Richard H. Drayton, Nature's Government: Science, Imperial Britain, and the 'Improvement' of the World (New Haven, CT: Yale University Press, 2000). 
found. ${ }^{62}$ Despite Morgan's confidence in the unfettered access to Antarctic icebergs on the high seas, Pyne in the late 1980s was less certain. He argued 'no claimant nation will allow ice to be removed without recognition of sovereignty, while no nonclaimant nation is likely to submit to extortion on the basis of territorial claims that it has never recognised as legitimate'. ${ }^{63}$ Nevertheless, if Australia's claims could be negotiated, water, that cursed limit on the nation's development, could be extracted from its southern neighbour through the dynamics of 'neo-ecological imperialism'. Such a regime, the historian Gregory Cushman argues, is the only alternative for colonising societies that choose neither to leave their territory and colonise new environments, nor to learn to live within their territory's ecological limits. ${ }^{64}$ Unlike the morally compromised phosphate imperialism under way in the Pacific, its absence of indigenous peoples made Antarctica the 'ideal settler colony' for a program of Australian water resource extraction to sustain its own settler colonial project. ${ }^{65}$

\section{Western Australian water dreaming}

Schwerdtfeger, meanwhile, had returned to Australia with renewed commitment and singled out Western Australia for particular attention. A month after the Iowa conference, the CSIRO state committee invited him to attend their December meeting in Perth, thus initiating a flurry of local interest in the prospect of iceberg utilisation. ${ }^{66}$ 'Big WA Role Seen in Iceberg Use', announced one headline, while another article reported '[a]n iceberg could provide enough water for WA for a year.

62 Adrian Howkins, 'Appropriating Space: Antarctic Imperialism and the Mentality of Settler Colonialism', in Making Settler Colonial Space: Perspectives on Race, Place and Identity, ed. Tracey Banivanua Mar and Penelope Edmonds (Basingstoke: Palgrave, 2010), 35-6. Pyne notes the contradiction of the imperial overtures towards Antarctica, which continued despite the post-war decolonising efforts of European empires under way in Africa, Asia and South America. See Pyne, The Ice, 319-22.

63 Pyne, The Ice, 356.

64 Gregory T. Cushman, Guano and the Opening of the Pacific World: A Global Ecological History (New York: Cambridge University Press, 2013), 76-8.

65 See Katerina Teaiwa, 'Ruining Pacific Islands: Australia's Phosphate Imperialism', Australian Historical Studies 46, no. 3 (2015), doi.org/10.1080/1031461X.2015.1082609; Howkins, 'Appropriating Space', 38. For further insights into settler Australia’s imperial relationship with Antarctica, see Christy Collis and Quentin Stevens, 'Cold Colonies: Antarctic Spatialities at Mawson and McMurdo Stations', Cultural Geographies 14, no. 2 (2007): 23454; Christy Collis, 'Mawson and Mirnyy Stations: The Spatiality of the Australian Antarctic Territory, 1954-61', Australian Geographer 38, no. 2 (2007): 215-31; Christy Collis, 'Mawson's Hut: Emptying Post-Colonial Antarctica', Journal of Australian Studies 22, no. 63 (1999): 22-9; Christy Collis, 'The Proclamation Island Moment: Making Antarctica Australia', Law Text Culture 8 (2004): 39-56; Tom Griffiths, Slicing the Silence: Voyaging to Antarctica (Sydney: UNSW Press, 2007); Brigid Hains, 'Mawson of the Antarctic, Flynn of the Inland: Progressive Heroes on Australia's Ecological Frontiers', in Ecology and Empire: Environmental History of Settler Societies, ed. Tom Griffiths and Libby Robin (Seattle, WA: University of Washington Press, 1997), 154-68; Brigid Hains, The Ice and the Inland: Mawson, Flynn and the Myth of the Frontier (Melbourne: Melbourne University Press, 2002).

66 J. Brophy to P. Schwerdtfeger, 10 November 1977. Iceberg Utilization-Transport. K637, 40, NAA. 
It could also provide energy worth five times the value of the water' ${ }^{67}$ The lone Western Australian delegate at the Iowa conference, Don Miles, told a reporter that iceberg harvesting 'could be the early 21 st century's C.Y. O'Connor schemesomething that sounds crazy, but may just prove the scoffers and critics wrong' ${ }^{68}$

Raising the spectre of O'Connor's ghost drew Schwerdtfeger's vision into Western Australia's own water dreaming. At the turn of the twentieth century, at the height of the colony's gold rush, O'Connor had designed and overseen the construction of an extraordinarily ambitious project - a pipeline to transport water uphill from the Darling Range near Perth to the thirsty mines of Coolgardie and Kalgoorlie, nearly $600 \mathrm{~km}$ away. Even the engineering schemes of ancient Rome had not been so bold as to pump water such a distance, let alone uphill. The historian Alan Atkinson describes the scheme as 'the most ambitious engineering project so far attempted in the Antipodes. ${ }^{69}$ At the pipeline's opening in 1903, Sir John Forrest, the state's first premier, referred to the prophet Isaiah (43:19) when he suggested that future generations would remember this achievement: 'They made a way in the wilderness and rivers in the desert'. ${ }^{70}$ But O'Connor was not there to celebrate this momentous occasion. With his project mired in controversy, and he the subject of vicious criticism from the local press, O'Connor had taken his own life less than a year before his vision was realised. ${ }^{71}$

The chair of the CSIRO Western Australia state committee had been head of the Western Mining Corporation in the early 1970s when it had investigated an even more ambitious project. During Laurence 'Brodie' Brodie-Hall's tenure as executive director, the corporation undertook a study to determine the feasibility of constructing a dam on the Fitzroy River in the state's north-west and pumping the water south to Perth and Kalgoorlie-a distance of more than 2,000 km. Although the corporation envisioned the Fitzroy proposal as a descendant of 'O'Connor's (Kalgoorlie) pipedream', conservative Premier Charles Court was less enthusiastic about the prospect. ${ }^{72}$ Seeing a conflict with his visions for the state's northern development, he argued in 1975: 'We cannot expect to reach too far with our pipelines to bring to Perth water that might be needed elsewhere'. ${ }^{73}$ Besides, the

67 'Big WA Role Seen in Iceberg Use', West Australian, 5 December 1977, 54; L. Brophy, 'Iceberg for WA could cost \$100m', Daily News, c. March 1978. Iceberg Technology Papers - CSIRO WA State Committee. K637, 41, NAA.

68 R. Banks, 'Iceberg water not just a dream-Wanneroo man', West Australian, c.1978. Iceberg Technology Papers-CSIRO WA State Committee. K637, 41, NAA.

69 Alan Atkinson, Nation, vol. 3 of The Europeans in Australia (Sydney: NewSouth Publishing, 2014), 164.

70 Ruth A. Morgan, 'Ghosts of the Water Dreamers: Water Histories between the Desert and the Sea', Griffith Review 47 (2015): 172.

71 Morgan, Running Out?, 39-40.

72 Morgan, Running Out?, 106.

73 Charles Court, 'Official Opening of the EPA and CSIRO Symposium on Groundwater Resources of the Swan Coastal Plain', in Groundwater Resources of the Swan Coastal Plain, ed. Barry A. Carbon (Perth: CSIRO Division of Land Resources Management, 1976), 1. 
Water Board's engineers calculated that it would cost the government nearly 60 times more to supply water from the north-west than would some of the other available options. ${ }^{74}$

The iceberg scheme offered a new avenue for the mining executive to explore. After Schwerdtfeger's visit, Brodie-Hall sought informal advice in Canberra as to whether the Western Australian Government would have Commonwealth support to develop iceberg utilisation technology. The state committee secretary confided to a CSIRO colleague: 'As icebergs are a renewable resource, the State Committee is most keen to encourage their exploitation in this manner and, while it produces a smirk or a chuckle, our Chairman (Brodie-Hall) intends pursuing the topic with some vigour'. ${ }^{75}$

Such water projects, bound to ambitions for the state's economic progress, were symptomatic of the state's unique brand of development ideology. Successive governments have taken great steps to help Western Australia overcome its national Cinderella status in order to attain, as the historian Lenore Layman argues, "'a greatness" to match its geographical area. ${ }^{76}$ This was the state that premier Charles Court would soon declare to be 'the land of movable mountains', and it was in this spirit that he maintained an interest in the iceberg proposal-'even though it might appear a little "far out" at the moment'. ${ }^{77}$ These local aspirations fostered the ideal conditions for a visioneer such as Schwerdtfeger. At a meeting with the state committee in May 1978, he noted: 'Australian interest in the icebert [sic] utilisation project would be in keeping with its long history of exploration in the Antarctic'. ${ }^{78}$ This appeal to a heroic past resonated strongly with the state's frontier mentality, born of the sheer size of the state, its geographical isolation and its economic dependence on mineral development. ${ }^{79}$

The Antarctic frontier offered Western Australians a more palatable counterpoint to the political and economic friction growing in the state's inland. On the eve of the Western Australian sesquicentenary, its developmentalist narrative was coming under fire: celebrating the pioneer's triumph celebrated the settler's possession of the land, its improvement and the assimilation of Indigenous landscapes into the settler

74 Morgan, Running Out?, 106.

75 J. Brophy to A. J. Nicholson, 7 April 1978. Iceberg Technology Papers_CSIRO WA State Committee. K637, 41, NAA.

76 Lenore Layman, 'Development Ideology in Western Australia, 1933-1965', Historical Studies 20, no. 79 (1982): 234-60. See also Ian Alexander, 'Western Australia: The Resource State', Australian Geographer 19, no. 1 (1988): 117-30.

77 Don Lipscombe and Kirwan Ward, The Land of Movable Mountains (Perth: Department of Tourism and Department of Industrial Development, 1978); C. Court to Under Secretary, 'Big WA Role Seen in Iceberg Use', 5 December 1977. Public Works Department. 10A02745C, WCWA.

78 CSIRO WA State Committee, 'Report on a Meeting held at [the] Public Works Department on May 1st 1978'. Iceberg Technology Papers - CSIRO WA State Committee. K637, 41, NAA.

79 G. C. Bolton, 'WAY 1979: Whose Celebration?', Studies in Western Australian History 10 (1989): 15-20. 
economy. ${ }^{80}$ Such a revision informed growing dissent about the environmental and cultural impacts of the mining industry in the state's north-west. By contrast, the Antarctic retained its allure as a 'place of possibility, an open future', what Howkins describes as 'an expansive mentality of constant progress' ${ }^{81}$ Here was a vast expanse for the redemption of settler pioneering masculinity-Australian women had only been allowed to work in Antarctica after $1975 .{ }^{82}$

Even the labour of iceberg utilisation invoked the frontier mythology of the state's pastoral north. Unpredictable and dangerous, icebergs seemed possessed of a wild nature themselves. The January 1978 issue of the magazine Popular Mechanics, for instance, described the 'tricky, tough, treacherous work' of towing icebergs away from 'endangered' oil rigs in the Labrador Sea. Its account of lassoing a 'formidable, crazy, unpredictable, rebellious' iceberg recalled the work of droving cattle across the Kimberleys. Icebergs were 'cantankerous, beastly, tricky' — creatures of an icy wilderness that needed to be tamed. ${ }^{83}$

At this stage, however, the reality of iceberg utilisation was more sedate. The feted iceberg of the Iowa conference had not simply been a publicity stunt. According to the conference planners:

it has been realised that many of the scientists and engineers involved in investigating the viability of using icebergs as a water resource lack the field experience and the familiarity with icebergs and their physical conditions. Trips to Antarctic or arctic ice shelves are not possible for people interested in iceberg utilisation due to physical and financial limitations. ${ }^{84}$

In short, if researchers could not get to the icebergs, then al-Faisal would bring the iceberg to them.

For their part at least, the Australian iceberg visioneers had considerable Antarctic experience. Budd had wintered in Antarctic in 1961 (Wilkes Station) and 1964 (Mawson Station), while Morgan had undertaken research at Wilkes in $1968 .{ }^{85}$ Although Schwerdtfeger had not visited the white continent, he had devised

80 John Hirst, 'The Pioneer Legend', Historical Studies 18, no. 71 (1978): 316-37. See also Andrea Gaynor, 'Colonists and the Land: An Environmental History of Nineteenth-Century Australia', in Making Australian History: Perspectives on the Past since 1788, ed. Deborah Gare and David Ritter (South Melbourne: Cengage, 2008), 144-53. 81 Hains, The Ice and the Inland, 5; Adrian Howkins, 'The Significance of the Frontier in Antarctic History: How the US West has shaped the Geopolitics of the Far South', Polar Journal 3, no. 1 (2013): 22, doi.org/10.1080/215 4896X.2013.768417.

82 Christy Collis, 'The Australian Antarctic Territory: A Man's World', Signs: Journal of Women in Culture and Society 34, no. 3 (2009): 514-19.

83 E. D. Fales, 'World's Biggest Moving Job - Icebergs!', Popular Mechanics (January 1978): 47-51, 106-13.

84 Information Service, 'Blue Iceberg Flew to ISU', c. October 1977. International Conference and Workshops on Iceberg Utilisation for Fresh Water Production, Weather Modification, and Other Applications. RS0/4/4 Box 1, Folder 91, ISU.

85 Budd's prominent position in the discipline of glaciology both in Australia and internationally is discussed in Alessandro Antonello's contribution to this special issue. 
equipment for measuring ice thickness that was applied at Mawson Station in $1965 .{ }^{86}$ Consequently, they could speak with authority on the topic of iceberg utilisation. As the historian Adrian Howkins observes, 'visiting the places we study is the sense of legitimacy that it confers ... Extreme environments heighten this sense of legitimacy. ${ }^{87}$ Legitimacy was a vital commodity for the vision of iceberg utilisation and its association with the tenacious discourses of heroic Antarctic exploration helped the cause. When Isaacs' iceberg scheme had surfaced in Australia in the late 1950s, a journalist reported his own discussions with Sir Douglas Mawson about the prospect: 'It shouldn't be impossible', the great Australian Antarctic explorer had declared. ${ }^{88}$ Others later used the pioneering device at the Ames conference, noting that Captain James Cook and his crew had used fragments of ice for water supplies during their voyage towards Antarctica in $1773 .^{89}$

\section{Dampening the water dreaming}

Beyond Western Australia, doubts were emerging about Schwerdtfeger's international partners. He was now acting as the Australian liaison for Iceberg Transport International (ITI), which al-Faisal had founded in the mid-1970s. ITI had subsequently established and funded a non-profit organisation, Icebergs for the Future (IFF), of which al-Faisal was chairman and the French polar explorer Paul Emile-Victor a director. The French engineer Georges Mougin, whom al-Faisal had first engaged to realise his iceberg vision, was managing director of both ITI and IFF. At a meeting of the Scientific Committee of IFF in Florida in March 1978, Schwerdtfeger was sanguine about the interest from state water managers and speculated on the use of the Australian polar vessel, the Nella Dan, for the committee's research. ${ }^{90}$ A representative of the Australian Antarctic Division who was also in attendance was generally supportive of the plans under discussion, though he made several references to Mougin's seemingly 'vague' explanation of the mechanisms for funding research. ${ }^{91}$ Based on this assessment, the division's director inferred that their British and American counterparts were 'cautious about

86 Ian Allison, 'Peter Schwerdtfeger and the Beginnings of ANARE Sea Ice Research', Aurora September (2014): $17-18$.

87 Adrian Howkins, “Have You Been There?” Some Thoughts on (Not) Visiting Antarctica', Environmental History 15, no. 3 (2010): 514-19.

88 S. W. Pennycuick, 'Cold Fact', The Age, 30 May 1957, 10.

89 Daniel J. Zaffarano, 'Introduction', in Iceberg Utilization, ed. Husseiny, xix; Richard L. Cameron, 'Glaciers and Icebergs', in Iceberg Utilization, ed. Husseiny, 32; I. A. el-Kassass, 'Potential Applications of Remote Sensing in Locating and Tracking of Antarctic Icebergs', in Iceberg Utilization, ed. Husseiny, 148; Zaffarano, 'Comments During Summary and Recommendations Session', in Iceberg Utilization, ed. Husseiny, 724.

90 J. S. Boyd, 'Attachment B: Overseas Visit Report'. Antarctic Program Administration, Advice, Economic Resources, Krill and Iceberg Utilisation for Fresh Water, 1976-1982. B1387, 81/70, NAA.

91 Boyd, 'Attachment B'. 
association with IFF'. He concluded: 'Clearly ITI Limited is seeking through IFF to use the international glaciological community and the Australian polar shipping program to further its objective of iceberg utilisation for commercial purposes, ${ }^{92}$

Within months of the IFF meeting, Schwerdtfeger's vision of Australian iceberg utilisation began to encounter difficulties. Although local water managers heard out his plan at a CSIRO state committee meeting in May 1978, they had already concluded that 'the economics of the exercise are too unfavourable to contemplate such a proposal this century, if ever, for Perth's water supply' ${ }^{93}$ The groundwater resources beneath the city's suburbs would provide a cheaper alternative to boost supplies in the foreseeable future. ${ }^{94}$ A similar rationale had also prevented the expansion of the state's Comprehensive Water Supply Scheme and the development of the Agaton groundwater scheme. As the Western Australian Department of Agriculture reported in 1981, '[e]conomic forces have moved against projects involving water transfer over great distances, and in favour of maximum local development of supplies'. ${ }^{95}$

But Schwerdtfeger was undeterred. He had returned from an ITI-sponsored meeting in the Britain in April 1980 committed to recruiting converts to the cause of iceberg utilisation. A more modest event than its Ames predecessor, the conference attendeesdrawn mostly from polar research institutes in Norway, Canada and Britain-had focused on the scientific and practical feasibility of such a scheme. Although iceberg utilisation retained Schwerdtfeger's confidence, other Australians who had attended the meeting were more cautious. Budd, now chief glaciologist of the Australian Antarctic Division, told the Melbourne Age: 'I don't think [towing an iceberg to Australia] would be worthwhile at the present time'. As for Prince al-Faisal and ITI's continued support, Budd's glaciologist colleague and fellow delegate Joe Jacka added: 'They remain confident but I'm not really sure why'. ${ }^{96}$ For Schwerdtfeger, however, the 'potentially enormous rewards, both economic and humanitarian' continued to far outweigh the challenges that iceberg utilisation posed. ${ }^{97}$

92 R. I. Garrod, 'Utilization of Icebergs'. 20 April 1978. Antarctic Program Administration, Advice, Economic Resources, Krill and Iceberg Utilisation for Fresh Water, 1976-1982. B1387, 81/70, NAA.

93 Chief Engineer to General Manager, 'Press Article re Use of Icebergs for Water Supply', 7 December 1977. Public Works Department. 10A02745C, WCWA.

94 CSIRO WA State Committee, 'Report on a Meeting held at [the] Public Works Department on May 1st 1978'. K637, 41, NAA.

95 Department of Agriculture, Annual Report of the Department of Agriculture for the Year ended 30th June 1981 (Perth: WA Department of Agriculture, 1982), 29.

96 'Iceberg Water Project Slows to Crawl', The Age, 10 June 1980, 3. In February 1980, Budd and Schwerdtfeger had hosted Mougin at a meeting at the University of Melbourne where Budd was also a professor of meteorology. See Australian Academy of Science, 'Scientific Discussion Meeting on Iceberg Utilisation, University of Melbourne', 28-29 February 1980. Public Works Department. 10A02745C, WCWA.

97 Peter Schwerdtfeger, 'On Icebergs and their Uses: A Report to the Australian Academy of Science', Cold Regions Science and Technology 1 (1979): 59-79. 
The Australian Academy of Science and the Western Australian Government were again Schwerdtfeger's audience. Through his mentor Rogers, Schwerdtfeger encouraged the Academy to assess the future availability of Australian water resources 'with icebergs as one possible solution'. ${ }^{98}$ The head of the Academy's National Committee for Hydrology was unmoved and outlined the difficulties such a scheme posed:

[I]n Victoria the project appeared infeasible because of the shallow water in Bass Strait, while in South Australia the use of icebergs rated the second most expensive option investigated. For Western Australia the iceberg proposal would involve some $15 \mathrm{~km}$ of undersea pipeline, and there would be great difficulties in integrating the new source of supply into the current system of surface reservoirs and shallow aquifers. Another considerable deterent [sic] in all cases was the environmental effect of a large ice mass in local waters and the local climate. ${ }^{99}$

Schwerdtfeger remained optimistic. In 1985, he recommended a West German firm, which had developed 'a quite novel wrapping technology' to prevent icebergs melting in transit, invite the Western Australian Water Authority to engage their services. ${ }^{100}$ The response, however, was unequivocal: the proposal was 'entirely unattractive' and the utility had 'no interest in purchasing iceberg water'. ${ }^{101}$

Aside from the technical difficulties and financial costs associated with iceberg utilisation, local water managers were also concerned about the environmental and political implications of such a scheme. Amongst themselves, they speculated as to the regional climatic effects of an iceberg 'parked offshore for several years' ${ }^{102}$ Another advised that 'such a project would receive little community support, in particular by environmentalists, and could result in bad publicity for the Water Authority should they support the project'. ${ }^{103}$ For more than a decade, the utility had come under close scrutiny from a growing local environmental movement that lacked confidence in its wise management of the surface and subterranean water resources of the south-west. ${ }^{104}$

98 N. H. Fletcher to W. P. Rogers, 8 November 1983; N. H. Fletcher to T. G. Chapman, 8 November 1983. MS160/1, Neville Horner Fletcher Collection, AAS.

99 T. G. Chapman to N. Fletcher, 'Use of Icebergs for Water Supplies in Australia', 20 July 1984. MS160/1, Neville Horner Fletcher Collection, AAS.

100 Peter Schwerdtfeger to Gordon Claridge, 23 August 1983. Government Relations, Advice, Possible Use of Antarctic Icebergs for Supply of Water. B1387, 86/347 Part 1, NAA; Ingenieurbüro für Abfalltechnik to R. Hillman, 'Drinking Water from Icebergs', 31 January 1985. Water Authority of Western Australia. 10F07309H, WCWA.

101 Chairman to P. Schwerdtfeger, 19 February 1985. Water Authority of Western Australia. 10A02745C, WCWA.

102 Anon., 2 June 1982. Public Works Department. 10A02745C, WCWA.

103 Peter Armanasco, 11 December 1986. Water Authority of Western Australia. 10F07309H, WCWA.

104 Morgan, Running Out?, 148. 
Meanwhile, a global coalition of environmental groups had formed to campaign against Antarctic resource exploitation. ${ }^{105}$ The proponents of iceberg utilisation had been largely unconcerned about the potential ecological impacts of their scheme. Although Weeks and Campbell had conceded that a moored iceberg would cause significant local changes to marine life, they were confident 'a new ecosystem would develop that might be more biologically productive'. Besides, they noted, icebergs were a more 'ecologically sound way of alleviating water scarcity than the more frequently mentioned seawater desalination techniques with their resultant great positive thermal pollution'. ${ }^{106}$ Similar views were presented in 1985 to the Senate Standing Committee on Natural Resources, which had undertaken to investigate the exploitation of the natural resources of the Australian Antarctic Territory. ${ }^{107}$ Budd, for instance, explained that local fish activity might even be encouraged due to the 'turning up of nutrients' in the process of harvesting icebergs, but 'this would not be detrimental'. ${ }^{108}$ More importantly, however, was the proximity of the icebergs to the area to which the Antarctic Treaty applied. As Morgan had reported in 1978, they lay beyond this area and so the committee concluded that ice would not be included in the impending minerals regime.

Although the committee's findings would help to sustain the vision of iceberg utilisation, Schwerdtfeger withdrew from its realisation and turned his attentions elsewhere. ${ }^{109}$ The limits on its accomplishment, he argued in 1985, lay not in science and technology, but in 'politically and economically based decisions'. He remained confident, however, that iceberg utilisation would eventuate when 'individual nations recognise their obligations to the more thirsty segment of mankind' and exploit the Antarctic icebergs that otherwise 'melt pointlessly in the Southern Ocean'. ${ }^{110}$ Two years later, another visioneer emerged with a scheme to harvest the 'almost limitless source of a vital commodity' from the Southern Ocean. A glaciologist who had accompanied an Australian Antarctic expedition in 1972, Murray RowdenRich shared his calculations for the Iceberg Harvester Project with the Antarctic Division and the governments of South Australia and Western Australia. ${ }^{111}$ Despite

105 Drew Hutton and Libby Connors, A History of the Australian Environment Movement (Cambridge: Cambridge University Press, 1999), 195-6.

106 Weeks and Campbell, 230.

107 Senate Standing Committee on Natural Resources, The Natural Resources of the Australian Antarctic Territory (Canberra: Australian Government Publishing Service, 1985).

108 Senate Standing Committee on Natural Resources, The Natural Resources of the Australian Antarctic Territory, 98-9.

109 John W. Zillman, 'The Remarkable German Contribution to Australian Meteorology', Proceedings of the Royal Society of Victoria 127, no. 1 (2015), doi.org/10.1071/RS15013.

110 Peter Schwerdtfeger, 'The Development of Iceberg Research and Potential Applications', Polar Geography and Geology 9, no. 3 (1985): 202-9.

111 R. J. M. Rowden-Rich, Preliminary Feasibility Study: Iceberg Export, January 1987. Government Relations, Advice, Possible Use of Antarctic Icebergs for Supply of Water. B1387, 86/347, Part 2, NAA. 
firm rejections from all parties, Rowden-Rich continued his campaign to harvest Antarctic icebergs into the mid-1990s, when the lack of financial support led him to set the project aside. ${ }^{12}$

\section{Water dreaming in a warming world}

One of the telltale signs of anthropogenic climate change is the warming of every continent over the past 50 years. How the Antarctic ice sheet is responding remains unclear-the temperature of the West Antarctic Peninsula is rapidly rising, while the East Antarctic ice sheet is seemingly growing and experiencing cooling. ${ }^{113}$ The reason for the cooling, according to Australian climate scientists, is that, as a result of global warming, the 'roaring forties' are becoming the 'furious fifties'. ${ }^{114}$ Over the past 70 years or so, these westerly winds have inched their way south across the Southern Ocean, steadily intensifying such that they are now stronger than at any time in the past thousand years. ${ }^{115}$ Their southerly movement has been trapping more cold air over the icy continent, resulting in greater snowfall in some areas of the Antarctic, which has kept its warming at bay.

Antarctica's gain, however, has been Australia's loss. Those westerly winds, those roaring forties that shaped Australia's European discovery, are largely responsible for winter rainfall in the south of the continent. In their march south, the westerlies have taken these rains with them and left the southern regions of Australia drier in their wake. Without a reduction in greenhouse gas emissions, the migration of the westerlies and the associated drying trend in southern Australia are only set to continue. Yet, this poleward drift of the westerly winds is just the latest step in the long, slow dance between these desert lands. They have been dancing in deep time ever since the final act in the break-up of Gondwanaland some 30 million years ago, when the Australian continent separated from Antarctica and inched towards the lower latitudes.

112 Bruno Spandonide, 'Iceberg Water Transportation from Antarctica to Australia' (PhD diss., University of Tasmania, 2012), 158.

113 Intergovernmental Panel on Climate Change, Climate Change 2013 The Physical Science Basis: Working Group I Contribution to the Fifth Assessment Report of the Intergovernmental Panel on Climate Change, ed. Thomas F. Stocker, Dahe Qin, Gian-Kasper Plattner, Melinda M.B. Tignor, Simon K. Allen, Judith Boschung, Alexander Nauels, Vincent Bex and Pauline M. Midgley (New York: Cambridge University Press, 2014).

114 Peter Hannam, 'Wilder winds, less rain, as roaring forties become furious fifties', Sydney Morning Herald, 11 May 2014. www.smh.com.au/environment/climate-change/wilder-winds-less-rain-as-roaring-forties-becomefurious-fifties-20140511-zr9b1.html, accessed 5 August 2017.

115 Nerilie J. Abram, Robert Mulvaney, Françoise Vimeux, Steven J. Phipps, John Turner and Matthew H. England, 'Evolution of the Southern Annular Mode during the past millennium', Nature Climate Change 4 (2014), doi.org/10.1038/nclimate2235. 
The scheme to use Antarctic icebergs for water supplies is then a chapter of a much longer Australian 'cryo-history', one that is as much about culture as it is about nature. ${ }^{116}$ In an era anxious about resource scarcity, visioneers saw in the white continent the means to a limitless future of water supplies and economic growth. Exploring these visions in their historical context emphasises the materiality of their concerns, the real-world problems that fuelled the visioneers. Because of the scale of their vision and the costs required for its realisation, it is tempting to dismiss their visions as speculative-mere science fiction - the products of the 'abundant imagination' of 'addicted frontierists'. ${ }^{117}$ Yet Schwerdtfeger and his colleagues were members of the scientific establishment, whose research and administration guided Australian policy in the Antarctic for several decades. ${ }^{118}$ In this respect, they resembled an earlier generation of Australian water dreamers-O'Connor, for instance, or the engineer John Bradfield, who designed the Sydney Harbour Bridge and produced a scheme to 'drought-proof' Queensland's arid interior. ${ }^{119}$

The iceberg visioneers of the 1970s and 1980s belonged to a wider debate about the earth's future, one that pitted the constraints of ecological limits against the possibilities of technological innovation. ${ }^{120}$ Just as the atom offered an inexhaustible source of cheap energy, Antarctica was a cornucopia of renewable fresh water simply awaiting the application of human ingenuity. To ignore this resource was to unnecessarily condemn the human race to an existence of zero growth. In this sense, iceberg utilisation was a humanitarian as well as economic and technological vision to slake the thirst of a growing global population and to ensure progress for all. ${ }^{121}$

Although the possibilists won out, theirs was a pyrrhic victory. In 2015, the World Economic Forum ranked water crises as the biggest threat facing the planet over the coming decade, and declared that the 'nexus of food, water, energy and climate change [was] one of four overarching mega trends that will shape the world in 2030'. ${ }^{122}$ Among the evidence cited were the prevailing drought conditions in California, which decades earlier Isaacs and the authors of the Rand study had deemed a potential site for iceberg utilisation. To forestall the drier future predicted

\footnotetext{
116 Sverker Sörlin, 'Cryo-History', in The New Arctic, ed. Birgitta Evengård, Joan Nymand Larsen and Øyvind Paasche (New York: Springer, 2015), 327-39.

117 J. M. Powell, 'Snakes and Cannons', 63; and J. M. Powell, 'Nature, Science and the Imperial Mosaic', Australian Geographer 41, no. 2 (2010): 249-64.

118 See, for example, Helen Mitchell, 'The Political Dynamics and Social Organization of Australian Antarctic Science: 1947-1987’ (Masters diss., University of Wollongong, 1988).

119 Sherratt and Griffiths, 234-54.

120 Paul Sabin, The Bet: Paul Ehrlich, Julian Simon, and Our Gamble over Earth's Future (New Haven, CT: Yale University Press, 2013).

121 Donald Worster, Shrinking the Earth: The Rise and Decline of American Abundance (New York: Oxford University Press, 2016), 157-82.

122 World Economic Forum, Global Risks Report 2015 (Geneva: World Economic Forum, 2015), 21.
} 
for southern California, San Diego has since invested in the biggest seawater desalination plant in the western hemisphere. The inspiration for this project? Perth, Western Australia. ${ }^{123}$

There, local water managers had dismissed the iceberg visioneers on the grounds that the 'need for such expensive schemes as desalination from sea water or proposals such as your iceberg project will not ... need to be considered for some time, if ever'. ${ }^{124}$ Even in the year 2000, the state's water resources minister had noted: 'The prospect of desalination on a large scale in Perth is still a long way off. ${ }^{125}$ Over the subsequent decade, however, Perth became the site of two seawater desalination plants that today dwarf the output of the San Diego scheme. ${ }^{126}$ Other Australian state capitals have followed suit, including Adelaide, another site earmarked for iceberg utilisation. For the Australian iceberg visioneers, desalination was always an undesirable option, which they assessed as more expensive and environmentally detrimental than their Antarctic scheme. ${ }^{127}$ What the recent turn to desalination in Australia and North America suggests, however, is that when it comes to insulating voters from the threat of breaching hydrological limits, never say never.

123 Ruth A. Morgan, 'The Allure of Climate and Water Independence: Desalination Projects in Perth and San Diego', Journal of Urban History (2017), doi.org/10.1177/0096144217692990.

124 Acting Manager, Corporate Planning to Murray Rowden-Rich, 19 January 1987. Water Authority of Western Australia. 10F07309H, WCWA.

125 Kim Hames, 'Foreword', in Desalination - creating new water sources (Leederville: Water Corporation, 2000), 1.

126 Morgan, 'The Allure of Climate and Water Independence'.

127 Schwerdtfeger, 'On Icebergs and their Uses'; 'Table 64: Adelaide Region: Cost of Alternative Water Supplies', c. 1977. Government Relations, Advice, Possible Use of Antarctic Icebergs for Supply of Water. B1387, 86/347, Part 1, NAA. 
This text is taken from International Review of Environmental History, Volume 4, Issue 1, 2018, edited by James Beattie, published 2018 by ANU Press, The Australian National University, Canberra, Australia.

doi.org/10.22459/IREH.04.01.2018.10 